MSC 47A10

DOI: $10.14529 / \mathrm{mmp} 190201$

\title{
INVERSE SPECTRAL PROBLEMS AND MATHEMATICAL MODELS OF CONTINUUM MECHANICS
}

G.A. Zakirova, South Ural State University, Chelyabinsk, Russian Federation, zakirovaga@susu.ru

The article contains results in the field of spectral problems for mathematical models with discrete semi-bounded operator. The theory is based on linear formulas for calculating the eigenvalues of a discrete operator. The main idea is to reduce spectral problem to the Fredholm integral equation of the first kind. A computationally efficient numerical method for solving inverse spectral problems is developed. The method is based on the Galerkin method for discrete semi-bounded operators. This method allows to reconstruct the coefficient functions of boundary value problems with a high accuracy. The results obtained in the article are applicable to the study of problems for differential operators of any order. The results of a numerical solution of the inverse spectral problem for a fourthorder perturbed differential operator are presented. We study some mathematical models of continuum mechanics based on spectral problems for a discrete semi-bounded operator.

Keywords: inverse spectral problem; discrete operator; fourth order operator; selfadjoint operator; eigenvalues; eigenfunctions; ill-posed problems.

Dedicated to the 60-th birthday of outstanding mathematician Jacek Banasiak.

\section{Introduction}

Let

$$
\Omega=\left\{x=\left(x_{1}, x_{2}, \ldots, x_{N}\right): 0<x_{j} \leq a_{j}, j=1, \ldots, N\right\}, a_{j}>0
$$

be a $N$-dimensional parallelepiped with lateral surface $\Gamma$. Let $L$ is a discrete semibounded operator on separable Hilbert space $H$ with domain $L_{2}[\Omega]$. Consider spectral problem

$$
\begin{gathered}
L u=\mu u, u \in L_{2}[\Omega], \\
\left.G u\right|_{\Gamma}=0 .
\end{gathered}
$$

We assume that the properties of some functions included in operator $L$ are known but their functional dependencies are not. Let us also know the eigenvalues of operator $L$ belonging to segment $[c, d]$. We set the following inverse spectral problem: to restore the functions included in operator $L$ in case, when eigenvalues $\left\{\mu_{k}\right\}_{k=1}^{n}$ of operator $L$ belonging to segment $[c, d]$ are known.

Today we know quite a few methods for solving the inverse spectral problem. The detailed description of these methods and their applicability can be found in review [43]. Let us dwell only on the method not mentioned in this review, later called the method of regularized traces. This method formed the basis for many of the studies mentioned later in 
this article. The ideas of the method were first formulated in the work of V.A. Sadovnichii and V.V. Dubrovskii [34]. Later, in articles [8,9] the theoretical justification of the method was given applied to inverse spectral problems for the perturbed Laplace operator. The theory of inverse problems for the Laplace operator with potential were further developed in works of V.A. Sadovnichii, V.V. Dubrovskii and their students [11, 12, 35, 36]. For example, in article [38] there were developed the algorithms of the approximate solution of the inverse spectral problem generated by the perturbed degree of Laplace operator. The inverse problem for perturbed degree $\beta>3 / 2$ of Laplace operator was solved [39]. In [13] the inverse problem for degree $\beta \geq N / 2$ of the Laplace operator was considered. In articles $[47,48]$ the inverse spectral problem for mathematical models with fractional degree of Laplace operator was considered.

The method of regularized traces formed the basis for studies of spectral problems carried out by S.I. Kadchenko. In [17] the method was developed that allows to calculate the eigenvalues of discrete semi-bounded operators of form $T+P$. Here $T$ is discrete semibounded operator and $P$ is restricted operator, given in separable Hilbert space $H$. The main idea of the method is as follows. Let eigenvalues $\left\{\lambda_{n}\right\}_{N=1}^{\infty}$ of operator $T$, numbered in non-decreasing order of their values taking into account the algebraic multiplicity, and orthonormal eigenfunctions $\left\{v_{n}\right\}_{n=1}^{\infty}$ of operator $T$ corresponding to $\lambda_{n}$ be known. Denote by $\nu_{n}$ multiplicity of eigenvalue $\lambda_{n}$, and by $n_{0}$ the number of all unequal eigenvalues of $\lambda_{n}$, which are lie inside circle $t_{n_{0}}$ of radius $\rho_{n_{0}}=\frac{\left|\lambda_{n_{0}+1}+\lambda_{n_{0}}\right|}{2}$ centered in the origin of the complex plane. Let $\left\{\mu_{n}\right\}_{n=1}^{\infty}$ are the eigenvalues of operator $T+P$, numbered in nondecreasing order of their real parts. If for all $n \in N$ inequalities $q_{n}=\frac{2\|P\|}{\left|\lambda_{n+\nu_{n}}-\lambda_{n}\right|}<1$ are satisfied then $\left\{\mu_{n}\right\}_{N=1}^{m_{0}}$ can be calculated by formulas

$$
\mu_{n}=\lambda_{n}+\left(P v_{n}, v_{n}\right)+\tilde{\delta}_{1}(n), \quad n=\overline{1, m_{0}},
$$

where for $\tilde{\delta}_{1}(n)$ the estimates are valid

$$
\left|\tilde{\delta}_{1}(n)\right| \leq(2 n-1) \rho_{n} \frac{q^{2}}{1-q}, \quad q=\max _{n \in N} q_{n}, \quad m_{0}=\sum_{n=1}^{n_{0}} \nu_{n} .
$$

It is worth noting that all of the above results are fair when there are some restrictions on the norm of perturbing operator $P$. So, equations (1) are obtained under the condition

$$
\|P\|<0,5\left|\lambda_{n+\nu_{n}}-\lambda_{n}\right|, \forall n \in N .
$$

This narrows down the class of problems to which the results can be applied. For research of applied problems it is necessary to develop such methods of analytical and numerical study of inverse spectral problems that would allow us to solve problems not tied to specific types of operators, and construct their solution for a sufficiently wide class of discrete semi-bounded operators. The development of such research methods will allow to conduct the study not only of existing problems, within the directions, but also of new problems described by differential or integro-differential equations.

In addition to the introductory part and the list of references, the article contains six paragraphs. The first section is devoted to finding eigenvalues of discrete semibounded operators. The second section provides a method for solving inverse spectral problems generated by discrete semibounded operators, which is based on the formulas obtained in the first paragraph. In the third paragraph the inverse spectral problem for the SturmLiouville operator generated by a fourth order differential equation is considered. In the 
fourth and fifth paragraphs, all abstract results are illustrated by concrete examples. The sixth section is devoted to the review of applications of inverse spectral problems.

Abstract methods developed by the author are applied to research of the following mathematical models:

1. Mathematical Model of Longitudinal Vibrations of the Rod with Variable Cross-Section

Equation

$$
m \frac{\partial^{2} u}{\partial t^{2}}=\frac{\partial}{\partial x}\left(E F \frac{\partial u}{\partial x}\right)
$$

with some homogeneous boundary conditions, describes the longitudinal or torsional vibrations of an elastic rod with a variable cross section. Here $m=m(x)$ is the mass of the rod length unit; $m=\rho ; \rho=\rho(x)$ is the material density distributed along the $\operatorname{rod} ; E=E(x)$ is the Young module; $F=F(x)$ is the cross-sectional area of the rod. Inverse spectral problems for the mathematical model of elastic rod oscillations in various formulations were considered in $[1,4,31]$.

2. Mathematical Model of Antiplane Vibrations of Elastic Layer

Antiplasma fluctuations of the elastic layer is described by following boundary problem $[4]$

$$
\begin{gathered}
\nabla^{2} \vec{u}+\frac{1}{1-2 \sigma} \nabla(\Theta)+\frac{\vec{F}}{G}=\frac{\rho}{G} \frac{\partial^{2} \vec{u}}{\partial t^{2}}, \\
\left.u_{y}\right|_{z=0}=\left.u_{y}\right|_{z=H}=0
\end{gathered}
$$

where $\vec{u}=\left(u_{x}, u_{y}, u_{z}\right)$ is a displacement vector, $H=$ const is a layer thickness, $\Theta=\nabla \vec{u}$, $(x, y, z)$ is Cartesian coordinate system, $\vec{F}=\left(F_{x}, F_{y}, F_{z}\right)$ is volume force, $G=$ const is a shear modulus, $\sigma$ is Poisson's ratio, $\rho(z)$ is a material density.

All mathematical models discussed above can be reduced to an operator equation of form

$$
L u=\mu u,
$$

where $L$ is a discrete lower semibounded operator in separable Hilbert space $H$. The study of these mathematical models is carried out in the framework of the following inverse spectral problem for equation (5). Let approximate eigenvalues $\left\{\widetilde{\mu}_{k}\right\}_{k=1}^{n}$ of operator $L$ be known. It is necessary to restore operator $L$ using its known eigenvalues.

\section{Computation of Eigenvalues of Discrete Lower Semibounded Operators by Modified Galerkin Method}

Definition 1. Operator $L$ acting in separable Hilbert space $H$ is called discrete if there exists some complex number $\lambda_{0}$ such that $R_{\lambda_{0}}=\left(L-\lambda_{0} E\right)^{-1}$ is a completely continuous operator in $H$.

Definition 2. Operator $L$ is called semibounded from below (on top), if there exists such real number $c$, that inequality

$$
(L f, f) \geq c(f, f), \quad((L f, f) \leq c(f, f))
$$

is satisfied for all $f \in \operatorname{dom} L$. 
Consider discrete semibounded operator $L$ given in separable Hilbert space $H$ with $\operatorname{dom} L \subset H$. Denote by $\Gamma$ the boundary of dom $L$. If $L$ is a differential operator, eigenvalues $\mu$ are determined by finding nontrivial solutions of equation

$$
L u=\mu u,
$$

that satisfy homogeneous boundary conditions

$$
\left.G u\right|_{\Gamma}=0 .
$$

To calculate them, we use the Galerkin method. We introduce sequence $\left\{H_{n}\right\}_{n=1}^{\infty}$ of finitedimensional spaces $H_{n} \subseteq H$, which is full in $H$. Let the orthonormal basis of space $H_{n}$ be known and consist of functions $\left\{\varphi_{k}\right\}_{k=1}^{n}$. Functions $\varphi_{k}$ must satisfy boundary conditions (7). Following the Galerkin method, the approximate solution of the spectral problem (6), (7) is found as

Write equation (6) as

$$
u_{n}=\sum_{k=1}^{n} a_{k}(n) \varphi_{k} .
$$

$(L-\lambda E) \varphi=(\mu-\lambda) \varphi$

for discrete operator $L$, there exists resolvent operator $R_{\lambda}(L)=(L-\lambda E)^{-1}$, which is completely continuous at $H$. Acting left on both parts of equation (8) with $R_{\lambda}(L)$ operator, we get

$$
\varphi=(\mu-\lambda) R_{\lambda}(L) \varphi .
$$

Based on [18] the Galerkin method applied to the problem of finding eigenvalues of the equation (9), a hence, equations (6) converges. Thus, the statements are fair

Theorem 1. [18] Let $L$ be a discrete semibounded from below operator acting in a separable Hilbert space $H$. If the system of coordinate functions $\left\{\varphi_{k}\right\}_{k=1}^{\infty}$ is a basis in space $H$, then the Galerkin method applied to the problem of finding the eigenvalues of spectral problem (6), (7), constructed on this system of functions, converges.

Theorem 2. [18] Let $L$ be a discrete semibounded from below operator acting in separable Hilbert space $H$. If the system of coordinate functions $\left\{\varphi_{k}\right\}_{k=1}^{\infty}$ is an orthonormal basis of $H$, then approximate eigenvalues $\widetilde{\mu}_{n}$ of operatorL can be found by

$$
\widetilde{\mu}_{n}(n)=\left(L \varphi_{n}, \varphi_{n}\right)+\delta_{n}
$$

where $\delta_{n}=\sum_{k=1}^{n-1}\left[\widetilde{\mu}_{k}(n-1)-\widetilde{\mu}_{k}(n)\right], \widetilde{\mu}_{n}(n)$ are $n$-th Galerkin approximations to corresponding eigenvalues $\mu_{n}$ of operator $L$.

If operator $L$ can be represented as $L=T+P$, where $T$ is a discrete semibounded operator and $P$ is a bounded operator in $H$, then operator $L=T+P$ is also discrete semibounded in $H$. Therefore, if coordinate function system $\left\{\varphi_{k}\right\}_{k=1}^{\infty}$ in Theorem 2 consists of orthonormal eigenfunctions $v_{k}$ of operator $T$ and satisfies boundary conditions (7), then for discrete semibounded operator $L=T+P$ formula (10) will take form (1). But in this case, it is not necessary to impose any restrictions on the norm of operator $P$.

Remark 1. Linear formulas (1) and (10) for calculating eigenvalues $\mu_{n}$ of $L=T+P$ operator are obtained on the basis of the regularized trace method and the Galerkin method. When conditions $q_{n}=\frac{2\|P\|}{\left|\lambda_{n+\nu_{n}}-\lambda_{n}\right|}<1$ for $\forall n \in N$ are met then (1) and (10) are equivalent. 
Theorem 3. Let $L$ be discrete semibounded from below operator acting in separable Hilbert space $H$. If the system of coordinate functions $\left\{\varphi_{k}\right\}_{k=1}^{\infty}$ is an orthonormal basis in $H$, then the Galerkin method in application to the problem of finding eigenvalues of spectral problem $L u=\mu u$, built on this system of functions, converges.

N.A. Polskiy introduced the so-called (A)-condition, or Polskiy condition of convergence of projective methods. He also noted that for a positive operator this condition in the Galerkin method is automatically. Thus, under the conditions of Theorem 2 and on the basis of the results of [26-28], the eigenvalues of (9) can be obtained as limits of their own elements. Therefore, we have a result

Theorem 4. If $L$ is a discrete semibounded operator acting in separable Hilbert space $H$, then there exists a unique solution of the problem of finding the eigenvalues of operator $L$. Approximate values of eigenvalues can be found by the Galerkin method.

If $\widetilde{\mu}_{k}(n)$ is the $n$-th approximate eigenvalue for $k$-th eigenvalue of $\mu_{k}$ of operator $L$ is found using Galerkin method, then, on the basis of Theorem 2 and 3 have

$$
\lim _{n \rightarrow \infty} \widetilde{\mu}_{k}(n)=\mu_{k}, k \in \mathbb{N} .
$$

Since for any $k \in N \lim _{n \rightarrow \infty}\left(\widetilde{\mu}_{k}(n-1)-\widetilde{\mu}_{k}(n)\right)=0$, for any $k \in N$ and for any $\varepsilon>0$ there exists number $N_{\varepsilon}$, for all $n>N_{\varepsilon}$ that inequalities are hold:

$$
\left|\widetilde{\mu}_{k}(n-1)-\widetilde{\mu}_{k}(n)\right|<\frac{\varepsilon}{k^{2}} .
$$

Then

$$
\left|\sum_{k=1}^{n-1}\left[\widetilde{\mu}_{k}(n-1)-\widetilde{\mu}_{k}(n)\right]\right| \leq \sum_{k=1}^{n-1} \frac{\varepsilon}{k^{2}}=\varepsilon \sum_{k=1}^{n-1} \frac{1}{k^{2}}=\varepsilon\left[\frac{\pi^{2}}{6}-\Psi(1, n)\right] \leq \varepsilon \frac{\pi^{2}}{6} .
$$

Here $\Psi(1, n)$ is a polygamma function. Therefore, $\lim _{n \rightarrow \infty} \delta_{n}=0$. Thus, the next Theorem holds.

Theorem 5. Let $L$ be a discrete semibounded operator acting in separable Hilbert space $H$. If the system of coordinate functions $\left\{\varphi_{k}\right\}_{k=1}^{\infty}$ is orthonormal basis $H$ and satisfies the homogeneous boundary conditions of spectral problem (6), (7), then the limit of the sequence of numbers $\delta_{n}$ included in formulas (10) at $n \rightarrow \infty$ is equal to zero

$$
\lim _{n \rightarrow \infty} \delta_{n}=0 .
$$

Formulas (10) allow us to find approximate values of discrete semibounded operators eigenvalues with a high computational efficiency. In contrast to the classical methods of computing the eigenvalues for discrete semibounded operators formulas (10) have several advantages: they drastically reduce the number of computations; solve the problem of finding eigenvalues of matrices of high order; allow us to find the eigenvalues of regardless of whether the eigenvalues with smaller numbers are known or not; solve the problem of calculating all the required points of the spectrum of the discrete semibounded operators. All of the above significantly increases the computational efficiency of (10) formulas compared to the classical Galerkin method. 


\section{Solution of Inverse Spectral Problems Generated by Perturbed Self-Adjoint Operators}

Using linear formulas (10) obtained on the basis of the Galerkin method, we construct a numerical method for solving inverse spectral problems generated by discrete semibounded operators.

Let operator $L$ in equation (6) be in form

$$
L=T+P
$$

where $T$ is a self-adjoint operator and $P$ is a bounded operator of multiplication by function $p(s), s \in[a, b]$ in separable Hilbert space $L_{2}(a, b)$. Assume that eigenvalues $\left\{\lambda_{k}\right\}_{k=1}^{\infty}$ and orthonormal eigenfunctions $\left\{\varphi_{k}\right\}_{k=1}^{\infty}$ of operator $T$ are known. Consider the problem of restoring potential $P$ by eigenvalues $\left\{\mu_{k}\right\}_{k=1}^{n}$ of operator $T+P$ in space $L_{2}(a, b)$.

Using (10), we construct an integral Fredholm equation of the first kind

$$
\int_{a}^{b} K(x, s) p(s) d s=f(x), C \leq x \leq d
$$

where functions $f(x)$ and $K(x, s)$ are such that

$$
f\left(x_{k}\right)=\widetilde{\mu}_{k}-\lambda_{k}-\int_{a}^{b} T\left(\varphi_{k}(s)\right) \varphi_{k}(s) d s+\delta_{k}, \quad K\left(x_{k}, s\right)=\varphi_{k}^{2}(s), c \leq x_{k} \leq d, \quad k=\overline{1, n} .
$$

If kernel $K(x, s)$ of integral equation (13) is continuous and closed in rectangle $\Pi=$ $[a, b] \times[c, d]$ and $p(s) \in W_{2}^{1}(a, b)$ and $f(x) \in L_{2}(c, d)$, then as it is known, the solution of equation (13) is unique. Based on the function definition $f(x)$, its values at points $x_{k}$ are known approximately. Denote through $\widetilde{f}\left(x_{k}\right)$ approximate values of function $f\left(x_{k}\right)$ such that $\left\|f\left(x_{k}\right)-\widetilde{f}\left(x_{k}\right)\right\| \leq \xi, \forall x_{k} \in[c, d]$. This estimate is used in the preparation of the algorithm of numerical solution of the problem.

Finding the solution of Fredholm integral equation of the first kind (13) is an ill-posed problem. The approximate solution $\widetilde{p}(s)$ can be found using the Tikhonov regularization. Numerical solution of equation (13) will determine an approximation $\widetilde{p}(s)$ of function $p(s)$ at nodal points $s_{i}, i=\overline{1, I}, a=s_{1}<s_{2}<\ldots<s_{I}=b$. To get good accuracy at interpolation functions $\widetilde{p}(s)$, the number of node points $I$ it is possible to choose large enough. Segment $[c, d]$ is chosen as follows, to find the accuracy of eigenvalues $\widetilde{\mu}_{n}$ found by formulas (10) belonging to this segment, met the specified requirements. Thus, using formula (10) managed to construct integral equation (13), which solution allows you to find approximate values $\widetilde{p}(s)$ operator $p(s)$ at node points $s_{i}$ of discretizations of segment $[a, b]$.

The developed method formed the basis of the numerical method of solution inverse spectral problems for discrete semibounded operators and set out in works of [19,20]. It should be noted that the method described above allows us to recover discrete semibounded operator $L$ in boundary value problem (6), (7) in case when $L$ is a differential expression of form

$$
L u=p_{0}(s) u^{(n)}+p_{1}(s) u^{n-1}+\ldots+p_{n}(s) u .
$$

Here $n$ is an order of differential operation. 


\section{Inverse Spectral Problem for the Sturm-Liouville Operator Generated by Fourth Order Differential Equation}

To illustrate that the modified Galerkin method is applicable to the operators of a high order, we consider the spectral problem generated by the operator of the Sturm-Liouville problem of the fourth order

$$
\begin{gathered}
u^{I V}+p_{4}(s) u=\mu u, \quad 0<s<1, \\
u(0)=u^{\prime}(0)=0, \quad u(1)=u^{\prime}(1)=0 .
\end{gathered}
$$

Function $p_{4}(s)$ is twice differentiable in $L(0,1)$. Let us compare the results of numerical calculations of eigenvalues of spectral problem (15), found by modified Galerkin method by formulas (10) and Galerkin method. For the system of coordinate functions $\left\{\varphi_{k}(s)\right\}_{k=1}^{n}$ in the Galerkin method, we take the eigenfunctions of spectral problem

$$
\begin{gathered}
\varphi^{I V}=\lambda \varphi \\
\varphi(0)=\varphi^{\prime}(0)=0, \quad \varphi(1)=\varphi^{\prime}(1)=0,
\end{gathered}
$$

which, as it is not difficult to show are following

$$
\begin{gathered}
\varphi_{k}(s)=C_{k}\left\{\operatorname{sh}\left[q_{k}(1-s)\right]+\sin \left[q_{k}(1-s)\right]-\operatorname{ch}\left(q_{k} s\right) \sin q_{k}+\right. \\
\left.+\operatorname{ch}\left(q_{k}\right) \sin \left(q_{k} s\right)+\operatorname{sh}\left(q_{k} s\right) \cos \left(q_{k}\right)-\operatorname{sh}\left(q_{k}\right) \cos \left(q_{k} s\right)\right\}, \quad k=\overline{1, \infty} .
\end{gathered}
$$

Numbers $q_{k}$ are the roots of transcendental equation

$$
1-\operatorname{ch} q \cos q=0 \text {. }
$$

The eigenvalues of spectral problem (16) are calculated by formulas

$$
\lambda_{k}=q_{k}^{4}, \quad k=\overline{1, \infty}
$$

In the Table we give approximate eigenvalues $\left\{\mu_{k}\right\}_{k=1}^{15}$ of spectral problem (15), found by formulas (10), and by the Galerkin method in the case when $p_{4}(s)=s^{2}+s+4-\sin (s)+\cos (3 s)$. A feature of the spectral problems under consideration (15), (16) is a sharp increase in eigenvalues with increasing their numbers, which creates computational difficulties when using the Galerkin method. This is due to the condition number of matrix which eigenvalues are found. If the condition number of the matrix $a\left(\right.$ cond $\left.(\mathrm{A})=\|A\| \cdot\|A\|^{-1}\right)$ is greater than $10^{3}$, it is assumed that the matrix $a$ is ill-conditioned. At the same time the accuracy of the problem is not enough to trust it. In this example, cond $(a)=1,67 \cdot 10^{8}$. In order to avoid errors, the calculation was carried out in

\begin{tabular}{|c|r|r|c|}
\hline \multicolumn{1}{|c}{ Table } \\
$k$ & $\lambda_{k}$ & $\widetilde{\mu}_{k}^{\delta}$ & $\left|\widetilde{\mu}_{k}^{\delta}-\widehat{\mu}_{k}\right|$ \\
& & & \\
\hline 1 & 500,6 & 504,9 & $1,7538 \cdot 10^{-5}$ \\
2 & 3803,5 & 3807,9 & $1,1298 \cdot 10^{-5}$ \\
3 & 14617,6 & 14622,0 & $3,5086 \cdot 10^{-6}$ \\
4 & 39943,8 & 39948,2 & $1,7538 \cdot 10^{-6}$ \\
5 & 89135,4 & 89139,8 & $1,3203 \cdot 10^{-7}$ \\
6 & 173881,3 & 173885,7 & $3,0283 \cdot 10^{-7}$ \\
7 & 308208,5 & 308212,9 & $1,7017 \cdot 10^{-7}$ \\
8 & 508481,5 & 508486,0 & $1,0278 \cdot 10^{-7}$ \\
9 & 793403,1 & 793407,6 & $6,5676 \cdot 10^{-8}$ \\
10 & 1184013,6 & 1184018,0 & $4,3907 \cdot 10^{-8}$ \\
11 & 1703691,1 & 1703695,5 & $3,0464 \cdot 10^{-8}$ \\
12 & 2378151,6 & 2378156,1 & $2,1819 \cdot 10^{-8}$ \\
13 & 3235449,0 & 3235453,5 & $1,6134 \cdot 10^{-8}$ \\
14 & 4305974,9 & 4305979,4 & $1,2903 \cdot 10^{-8}$ \\
15 & 5622458,8 & 5622463,2 & $5,0973 \cdot 10^{-8}$ \\
\hline
\end{tabular}


the mathematical package Maple. The length of the mantissa for operations with real numbers was taken equal to 191. Such problems do not arise when using the modified Galerkin method to find eigenvalues by formulas (10).

The considered example, calculations of eigenvalues of semibounded discrete operators by the modified Galerkin method and its comparison with the results obtained by the classical Galerkin method confirm the validity of formulas (10).

\section{Mathematical Model for Determining the Anomaly of Water Density on the Resonant Frequencies of the Oscillations Antiplastic}

In the recent years there is the possibility of remote sensing the thickness of the ocean with artificial satellites. Free on top the ocean's internal waves are manifested in the form of light reflections moving with the phase velocity of internal waves. With artificial satellites can be fixed these highlights and measure the speed of their movement on the free surface of the ocean. Determining the phase velocity of propagation by photos from space internal waves and their length, density distribution can be calculated by depth and thus determine the location of the anomalous density (any objects in the deep ocean). Such objects can be jambs fish, submarines, bathyscaphe, divers, wrecks and so on.

Consider the problem of restoring the distribution of water density deep in the ocean for specific regions on the phase characteristics internal waves at the free surface, using conventional Oceanographic productions [24]. Initial works known to us in the field of inverse problems of wave motions inhomogeneous liquid are the works by S.A. Grodsky, V.N. Kudryavtsev, L.V. Cherkesov, I.T. Selezov. Currently, actively studying such tasks are engaged in E.N. Potetyunko (for example [29]).

Consider the elastic layer with thicknesses $H=$ const, fixed at both boundaries $z=0$ and $z=H$ and extending to infinity along the horizontal destinations [30]. The origin is taken on the bottom base of the layer, axis $z$ is directed vertically upwards, axis $x, y$ are directed horizontally. In the Oceanological formulation of the problem of free oscillations of the stratified ocean in Boussinesq approximations and "solid covers" for amplitude function of vertical oscillations of fluid particles the problem is reduced to following boundary value problem [24]

$$
\begin{gathered}
W^{\prime \prime}(z)-\frac{\beta(z)}{g} W^{\prime}(z)+\frac{\beta(z)-\omega^{2}}{\omega^{2}-f^{2}} k^{2} W(z)=0, \quad-H<z<0, \\
W(-H)=0, \quad W^{\prime}(0)-\frac{g k^{2}}{\omega^{2}-f^{2}} W(0)=0, \\
\beta(z)=-\frac{g}{\rho_{0}} \rho_{0}^{\prime}(z) .
\end{gathered}
$$

Here $W$ is a function of the amplitude of oscillations of fluid particles in the direction of $O z$ axis; $\beta(z)$ is a square of the frequency buoyancy (Brent-Vaisala frequency). Brent-Vaisala frequency is introduced for stable stratification (fluid density increases with increasing depth) and characterizes the frequency of small free oscillations of water particles near $z$ level; $\rho_{0}(z)$ is the density of the fluid in the equilibrium state( density of undisturbed ocean); $\omega$ is circular frequency of free oscillations of an inhomogeneous liquid; $k$ is the wave number corresponding the frequency in the vertical oscillations of the particles of inhomogeneous fluid; $g$ is the acceleration of gravity; $\rho_{0}(z)$ is the density of the fluid in the 
equilibrium state, corresponding to the state of rest of the liquid; $f=2 \Omega \sin \varphi$ is Coriolis force; $\Omega$ is the angular velocity of the earth's rotation; $\varphi$ is latitude of the area in which the internal waves are considered; $H=$ const is water depth. The mathematical model with different boundary conditions was also considered in the Boussinesq approximation when the boundary value of the problem is fell, and in approximation of a "rigid cover", when the boundary condition on the free surface is replaced by condition $W(0)=0$. We also consider the problem in the Boussinesq approximation and "hard cover" at the same time.

Take the origin on the undisturbed surface of the liquid, $O z$ axis is directed vertically upwards against the force gravity [3]: compared to other members of equations (20), summand $-\frac{\beta(z)}{g} W^{\prime}$ little, therefore, in the future we will use the Boussinesq approximation [24]. For this case, equation (20) is written as:

$$
W^{\prime \prime}(z)+\frac{\beta(z)-\omega^{2}}{\omega^{2}-f^{2}} k^{2} W(z)=0 .
$$

For any stratification and sufficient depth of the liquid, there is a surface wave propagating under the law of homogeneous liquid [3]:

$$
\begin{gathered}
\omega^{2}=\frac{-f^{2}+\sqrt{f^{4}+4 g^{2} k^{2}}}{2}, \\
\omega=\sqrt{g k}, \quad f=0 .
\end{gathered}
$$

When processing the measured spectral characteristics from consideration should exclude frequencies that are close to designated relations (23) and non-carrying information on inhomogeneity liquids. Elimination of such frequencies can be carried out by replacing boundary condition in (20) for $z=0$ with condition

$$
W(0)=0 .
$$

As a result of simplifications we come to the boundary value problem

$$
\begin{gathered}
W^{\prime \prime}(z)+\frac{\beta(z)-\omega^{2}}{\omega^{2}-f^{2}} k^{2} W(z)=0, \\
W(0)=W(-H)=0 .
\end{gathered}
$$

The values of function $\beta(z)$ found based on the solution of the inverse spectral problems (24), (25) are compared with background distribution of buoyancy frequency and deviations from background density perturbations are determined in a given ocean area [24]. Denote

$$
p_{0}(z)=\frac{\omega^{2}-f^{2}}{\beta(z)-\omega^{2}},
$$

and write spectral problem (24), (25) as

$$
\begin{gathered}
p_{0}(z) W^{\prime \prime}=-k^{2} W, \quad-H<z<0, \\
W(0)=W(-H)=0 .
\end{gathered}
$$

By entering dimensionless variable $\xi=\frac{z}{H}+1$, we have

$$
\begin{gathered}
p_{0}(\xi) W^{\prime \prime}(\xi)=\mu W(\xi), \quad 0<\xi<1, \\
W(0)=W(1)=0,
\end{gathered}
$$


where $\mu=-H^{2} k^{2}$.

Known pairs $\left(k_{n}, \omega_{n}\right), n=\overline{1, N_{s}}$, lying on different dispersion curves using the solution of inverse spectral problem $(29),(30)$, are determined by the values of function $p_{0}(z)$ in the nodes of the discretization. Knowing $p_{0}(z)$, using (26), we can find the values of function $\beta(z)$ and water density $\rho_{0}$. To do this, use equation from (22)

$$
\frac{d \rho_{0}}{d z}=-\frac{\beta(z)}{g} \rho_{0}
$$

in equation (31) let's replace with variable $z=H(\xi-1)$, then

$$
\frac{d \rho_{0}}{d \xi}=-\frac{H \beta(\xi)}{g} \rho_{0} .
$$

The general solution of a differential equation with separating variables (32) is

$$
\rho_{0}(\xi)=C e^{-\frac{H}{g} \int_{0}^{\xi} \beta(\zeta) d \zeta}, \quad 0 \leq \xi \leq 1 .
$$

Using initial condition $\rho_{0}(1)=\rho_{*}$, we obtain

$$
\rho_{0}(\xi)=\rho_{*} e^{\frac{H}{g} \int_{\xi}^{1} \beta(\zeta) d \zeta},
$$

where $\rho_{*}$ is the density of the liquid at its upper boundary at $\xi=1$. Expressing $\beta$ from formula (26), we write

$$
\rho_{0}(\xi)=\rho_{*} e^{\frac{H}{g} \int_{\xi}^{1}\left[\omega^{2}+\frac{\omega^{2}-f^{2}}{p_{0}(\zeta)}\right] d \zeta} .
$$

Thus, the problem of restoring the anomalous distribution of water density in the ocean for its specific areas by the phase characteristics of internal waves manifested on the free surface is reduced to inverse spectral problem

where $\mu=-H^{2} k^{2}$.

$$
\begin{gathered}
p_{0}(\xi) W^{\prime \prime}(\xi)=\mu W(\xi), \quad 0<\xi<1, \\
W(0)=W(1)=0,
\end{gathered}
$$

The found distribution of function $\beta(z)$ will solve the problem on free oscillations of a vertically stratified fluid, which, in disregard of dissipative effects (viscosity, thermal conductivity, diffusion), reduces to Sturm-Liouville problem relative to the amplitude function of the vertical velocity component liquid particles.

\section{Mathematical Model of Physical and Geometrical Heterogeneities of the Elastic Rod Recovery at the Resonance Frequencies of the Longitudinal Oscillations} [30]

We consider the problem of longitudinal vibrations of a rod with variable cross section

$$
m \frac{\partial^{2} u}{\partial t^{2}}=\frac{\partial}{\partial x}\left(E F \frac{\partial u}{\partial x}\right)
$$

where $m=m(x)$ is the mass of the rod length unit; $m=\rho F ; \rho=\rho(x)$ is the material density distributed along the rod; $E=E(x)$ is the Young module; $F=F(x)$ is the crosssectional area of the rod. We will search for the periodic solution of equation (36) in the form

$$
u(x, t)=U(x) e^{i \omega t} .
$$


Substituting (37) into (36), we obtain

Denote

$$
U^{\prime \prime}+\frac{(E F)^{\prime}}{E F} U^{\prime}+\frac{m}{E F} \omega^{2} U=0 .
$$

$$
\begin{gathered}
E F=\psi, \quad \frac{m}{E F}=\frac{\rho}{E}=\frac{1}{c^{2}}, \quad m=m_{0}+m_{1}(x), \\
\rho=\rho_{0}+\rho_{1}(x), \quad \rho_{0}=m_{0} F, \quad m_{1}=\rho_{1} F, \rho_{0}, m_{0}=\mathrm{const}, \\
\frac{m_{0}}{E F}=\frac{\rho_{0}}{E}=\frac{1}{c_{0}^{2}} .
\end{gathered}
$$

Here $c=c(x)$ is the local speed of sound for the derivative of density $\rho(x)$ and an arbitrary Young's module of $E(x) ; c_{0}=c(x)$ is the local speed of sound for constant density $\rho_{0}$ and an arbitrary young's module of $E(x) ; m_{1}(x)$ is the mass deviation from the constant; $\rho_{0}(x)$ is deviation of the density from a constant. In equation (38) replace variable $U$ :

$$
U(x)=\frac{y(x)}{\sqrt{\psi}}
$$

and find $U^{\prime}$ and $U^{\prime \prime}$

$$
U^{\prime}=\frac{2 y^{\prime} \psi-y \psi^{\prime}}{2 \psi^{\frac{3}{2}}}, U^{\prime \prime}=\frac{2 y^{\prime \prime} \psi+y^{\prime} \psi^{\prime}-y \psi^{\prime \prime}}{\psi^{\frac{3}{2}}}-\frac{3}{2} \frac{\psi^{\prime}}{\psi} U^{\prime} .
$$

Substituting the found values of derivatives into equation (38), we obtain

$$
\frac{2 y^{\prime \prime} \psi+y^{\prime} \psi^{\prime}-y \psi^{\prime \prime}}{\psi^{\frac{3}{2}}}-\frac{3}{2} \frac{\psi^{\prime}}{\psi} U^{\prime}+\frac{\psi^{\prime}}{\psi} U^{\prime}+\frac{m}{E F} \omega^{2} \frac{y}{\sqrt{\psi}}=0,
$$

or

$$
\frac{2 y^{\prime \prime} \psi+y^{\prime} \psi^{\prime}-y \psi^{\prime \prime}}{\psi^{\frac{3}{2}}}-\frac{\psi^{\prime}}{2 \psi} \frac{2 y^{\prime} \psi-y \psi^{\prime}}{2 \psi^{\frac{3}{2}}}+\frac{m}{E F} \omega^{2} \frac{y}{\sqrt{\psi}}=0,
$$

or

$$
y^{\prime \prime}+\left(\frac{m}{E F} \omega^{2}+\frac{\left(\psi^{\prime}\right)^{2}}{4 \psi^{2}}-\frac{\psi^{\prime \prime}}{2 \psi}\right) y=0
$$

Since

$$
\frac{m}{E F}=\frac{m_{0}+m_{1}}{E F}=\frac{\rho_{0}+\rho_{1}}{E}=\frac{1}{c_{0}^{2}}+\frac{\rho_{1}}{E},
$$

that

$$
y^{\prime \prime}+\left(\frac{\omega^{2}}{c_{0}^{2}}+\frac{\rho_{1} \omega^{2}}{E}+\frac{1}{4}\left(\frac{\psi^{\prime}}{\psi}\right)^{2}-\frac{\psi^{\prime \prime}}{2 \psi}\right) y=0 .
$$

In the resulting equation, we replace $x=l \xi$ and $y(x)=y(l \xi)=f(\xi)$ (here $l$ is the length of the rod)

$$
f^{\prime \prime}+\left(\frac{\omega^{2} l^{2}}{c_{0}^{2}}+\frac{\rho_{1} \omega^{2} l^{2}}{E}+\frac{1}{4}\left(\frac{\psi^{\prime}}{\psi}\right)^{2}-\frac{\psi^{\prime \prime}}{2 \psi}\right) f=0 .
$$

Hence

$$
\frac{1}{1+\varphi(\xi)} f^{\prime \prime}+\frac{\beta(\xi)}{1+\varphi(\xi)} f=-\Omega^{2} f
$$

here $\varphi(\xi)=\frac{\rho_{1} c_{0}^{2}}{E}, \beta(\xi)=\frac{1}{4}\left(\frac{\psi^{\prime}}{\psi}\right)^{2}-\frac{\psi^{\prime \prime}}{2 \psi}, \Omega^{2}=\frac{\omega^{2} l^{2}}{c_{0}^{2}}$. 
The spectral problem is considered for the construction of algorithms for the reconstruction of physical and geometric inhomogeneities of the elastic rod by resonant frequencies at longitudinal oscillations

$$
\begin{gathered}
\frac{1}{1+\varphi(\xi)} f^{\prime \prime}+\frac{\beta(\xi)}{1+\varphi(\xi)} f=-\Omega^{2} f, \\
f(0)=f(1)=0 .
\end{gathered}
$$

We consider special case $E=$ const. Let area $F$ of cross section of the rod and its mass $m$ change according to the laws

$$
F=F_{0}[1+\eta(\xi)], \quad m=m_{0}[1+\zeta(\xi)], \quad \xi \in[0,1] .
$$

Then from equations (39), we have

$$
\begin{gathered}
\rho_{1}(\xi)=\frac{m_{1}}{F_{0}}=\frac{m_{0}}{F} \frac{\zeta(\xi)}{1+\eta(\xi)}, \quad \psi(\xi)=E F_{0}[1+\eta(\xi)], \\
\beta(\xi)=\frac{\left[\eta^{\prime}(\xi)\right]^{2}}{4[1+\eta(\xi)]^{2}}-\frac{\left[\eta^{\prime \prime}(\xi)\right]}{2[1+\eta(\xi)]} \\
\varphi(\xi)=\frac{m_{0} c_{0}^{2}}{E F_{0}} \frac{\zeta(\xi)}{1+\eta(\xi)}=\frac{m_{0}}{E F_{0}} \frac{E F}{m_{0}} \frac{\zeta(\xi)}{1+\eta(\xi)}=\zeta(\xi) .
\end{gathered}
$$

We write spectral problem (40), (41) as

$$
\begin{gathered}
-p_{0}(\xi) f^{\prime \prime}(\xi)-p_{2}(\xi) f(\xi)=\mu f(\xi), \quad 0<\xi<1, \\
f(0)=f(1)=0,
\end{gathered}
$$

here

$$
p_{0}(\xi)=\frac{1}{1+\zeta(\xi)}, \quad p_{2}(\xi)=\frac{\beta(\xi)}{1+\zeta(\xi)}, \quad \mu=\Omega^{2} .
$$

Functions $p_{0}(\xi), p_{2}(\xi)$ are continuous on the segment $[0,1]$ and in this case $p_{0}(\xi) \neq 0$ for $\forall \xi \in(0,1)$. Get the equation for finding the values of function $\eta(\xi)$, specifying distribution of the cross-sectional area of the rod. Using equals (45), find

$$
\beta(\xi)=\frac{p_{2}(\xi)}{p_{0}(\xi)}=\frac{\eta^{\prime}(\xi)^{2}}{4[1+\eta(\xi)]^{2}}-\frac{\eta^{\prime \prime}(\xi)}{2[1+\eta(\xi)]} .
$$

Hence

$$
2[1+\eta(\xi)] \eta^{\prime \prime}(\xi)-\eta^{\prime}(\xi)^{2}+\frac{4 p_{2}(\xi)}{p_{0}(\xi)}[1+\eta(\xi)]^{2}=0 .
$$

Assume that the values of $\eta(0), \eta(1)$ are known

$$
\eta(0)=\eta_{0}, \quad \eta(1)=\eta_{1} .
$$

As a result, for finding $\eta(\xi)$ a nonlinear boundary value problem (46), (47) is obtained which solution can be found by numerical methods. Consider two special cases where $F=F_{0}=$ const and $\rho=\rho_{0}=$ const. In the first case, the density distribution of the material along the rod is as follows

$$
\rho=\frac{m_{0}}{F_{0}}[1+\zeta(\xi)]
$$


In the second case, the cross-sectional area of the rod is calculated by formula

$$
F=\frac{m_{0}}{\rho_{0}}[1+\zeta(\xi)]
$$

It is shown that the developed method for solving inverse spectral problems makes it possible to determine the physical and geometric inhomogeneities of an elastic rod by resonant frequencies at its longitudinal and torsional vibrations.

\section{Applications of Inverse Spectral Problems}

As it is known, the inverse problem of spectral analysis means restoration of differential operators by some their spectral characteristics. Due to the need to address new feedbacks spectral problems, and describe complex technical processes the interest in this subject is constantly increases.

The results in the inverse spectral problems theory are applicable in many industries natural science. Developed by G.A. Sviridyuk the relative spectral theory $[16,49]$ allows us to investigate those mathematical models to which the classical methods of spectral operator theories are not applied. Relevance of the spectral problems for discrete semibounded operators are due to not only a fundamental interest in this issue, but also to the need to study important applications, in particular, in mechanics, physics, electronics, Geophysics, Metrology, seismic exploration, identification of composite materials and other areas of science and technology. We constantly face with the phrase "spectral problems have wide application in various fields of natural science". Let finally bring the disparate facts in a more or less coherent whole.

For example, in solid mechanics inverse spectral problems allow us to determine the anomalous density in the depths of the ocean on the speed of propagation of internal waves and their length $[7,32]$. The problems of non-destructive control of building structures can be reduced to inverse spectral problems too [4]. In this tasks it is necessary to determine the density and structure of the material in the entire construction, when resonant oscillation frequencies of individual building elements are known. In optics, problems of this kind arise in determining the refractive index profile, which provides equidistantly spectrum of waveguide models [40]. Moreover, inverse problems are widely used in radio electronics in the synthesis of parameters non-uniform transmission lines with specified technical specifications [22,23], in the theory of elasticity in determining the size of cross sections beams at given frequencies of its own oscillations [44].

Inverse spectral problems have a wide application in such sections of physics, as quantum chromodynamics, molecular physics, the theory of the nucleus, where the model potentials are widely used. For example, the problem of determining the scattering phases from the observed experimental data in scattering reactions of [6]. The solving of inverse spectral problems in quantum mechanics allows to determine the atomic forces according to the known energy levels (i.e. spectrum), control the transparency of quantum systems, tunneling $[37,45]$.

In Geophysics such problems arise when you search for natural mineral deposits in the measured vibrations of soil, rocks, water masses on the surface, in determining the density and Lame parameters, describing the properties of the Earth, in determining the electrical permeability and conductivity, magnetic permeability by measurements electromagnetic fields, or acoustic velocity by measurements sound $[2,21]$, in determining 
the temperature profile of the measured thermal spectrum atmospheric radiation by thermal sensing of the atmosphere [33], etc. The tasks in different issues of observability and identification controlled systems, issues of computer diagnostics of technical natural oscillation frequencies and control systems frequency-resonance characteristics of various technical devices described by linear dynamic systems also reduce to inverse spectral problems $[5,14,15,25,41,42,46]$.

Acknowledgements. The work was supported by Act 211 Government of the Russian Federation, contract no. 02.A03.21.0011.

\section{References}

1. Akhtyamov A.M., Galeeva D.R. Identification of Length, Density and Elastic Modulus of Corrosion Part of the Rod by Natural Frequencies of Longitudinal Vibrations. Bulletin of Bashkir University, 2015, vol. 20, no. 2, pp. 398-402. (in Russian)

2. Anderssen R.S. The Effect of Discontinuities in Destiny and Shear Velocity on the Asymptotic Overtone Structure of Tortional Eigenfrequencies of the Earth. Astronomical Sciences, 1997, vol. 50, pp. 303-309. DOI: 10.1111/j.1365-246X.1977.tb04175.x

3. Anosova Ye.A., Potetunko E.N., Scherbak Ye.N. Parameters of Physically Non-Homogenous Media Reconstructed from the Eigenfrequencies of Their Free Oscillations. Journal of Engineering Mathematics, 2006, vol. 55, pp. 339-356. DOI: 10.1007/s10665-006-9032-7

4. Anosova E., Herskowitz I., Potetynko E.N., Srubshchik L.S. Assesment of the Efliqciency of the Structure Foundation by the Resonanse Frequencies of its Anti Planar Vibrations. International Congress "Strures Congress and the Forensic Engineering Symposium", N.Y., 2005, pp. 1-12. DOI: 10.1061/40753(171)119

5. Vibracii $v$ tekhnike: Kolebaniya lineynyh sistem [Vibrations in Technology: Fluctuations of Linear Systems]. Moscow, Mashinostroenie, 1978. (in Russian)

6. Bykov A.A., Dremin I.M., Leonidov A.V. [Potential Models of Quarkonia]. Uspekhi fizicheskih nauk [Physics-Uspekhi], 1984, vol. 143, no. 1, pp. 3-32. DOI: 10.3367/UFNr.0143.198405a.0003 (in Russian)

7. Cherkesov L.V., Potetunko E.N., Shubin D.S. Reconstruction of Ocean Density Distribution from Its Wave Spectrum. International Journal of Fluid Mechanics Research, 2003, vol. 30, no. 1, pp. 11-23. DOI: 10.1615/InterJFluidMechRes.v30.i1.20

8. Dubrovskii V.V., Nagorny A.N. On an Inverse Problem for the Laplace Operator with Continuous Potential. Differential Equations, 1990, vol. 26, no. 9. pp. 1156-1159.

9. Dubrovskii V.V., Nagorny A.N. The Inverse Problem for Degree of Laplace Operator with a Potential from $L^{2}$. Differential Equations, 1992, vol. 28, no. 9, pp. 1552-1561.

10. Dubrovskii V.V. On Stability of Inverse Problems of Spectral Analysis for Equations of Mathematical Physics. Russian Mathematical Surveys, 1994, vol. 49, no. 3, pp. 183-184.

11. Dubrovskii V.V. Operator Recovery by Eigenvalues of Various Problems. Russian Mathematical Surveys, 1996, vol. 51, no. 4, pp. 732-733. DOI: 10.1070/RM1996v051n04ABEH002978

12. Dubrovskii V.V. The Existence Theorem in the Inverse Problem of Spectral Analysis. Differential Equations, 1997, vol. 33, no. 12, pp. 1707-1709. 
13. Dubrovskii V.V. Obratnye zadachi spektral'nogo analiza dlya nekotoryh differencial'nyh operatorov $v$ chastnyh proizvodnyh [Inverse Spectral Analysis Problems for Some Partial Differential Operators: PhD Thesis]. Magnitogorsk, Magnitogorsk State University, 2006.

14. Egorov A.I. Osnovy teorii upravleniya [Fundamentals of Control Theory]. Moscow, Fizmatlit, 2004. (in Russian)

15. Graham M., Glehdvell L. Obratnye zadachi teorii kolebaniy [Inverse Problems of the Theory of Oscillations]. Izhevsk, RHD, 2008. (in Russian)

16. Favini A., Sviridyuk G.A., Manakova N.A. Linear Sobolev Type Equations with Relatively p-Sectorial Operators in Space of "Noises". Abstract and Applied Analysis, 2015, vol. 2015, article ID: 697410, 8 p. DOI: 10.1155/2015/697410

17. Kadchenko S.I., Kakushkin S.N. Chislennye metody regulyarizovannyh sledov spektral'nogo analiza [Numerical Methods of Regularized Traces of Spectral Analysis]. Chelyabinsk, Publishing SUSU, 2015. (in Russian)

18. Kadchenko S.I. Numerical Method for Solving Inverse Spectral Problems Generated by Perturbed Self-Adjoint Operators. Vestnik SamGU. Estestvennonauchnaya seriya, 2013, no. 9, pp. 5-11. (in Russian)

19. Kadchenko S.I., Zakirova G.A. A Numerical Method for Inverse Spectral Problems. Bulletin of the South Ural State University. Series: Mathematical Modelling, Programming and Computer Software, 2015, vol. 8, no. 3, pp. 116-126. DOI: 10.14529/mmp150307

20. Kadchenko S.I. Numerical Method for Solving of Inverse Spectral Problems Generated by Perturbed Self-Adjoint Operators. Vestnik Samarskogo Universiteta. Estestvenno-Nauchnaya Seriya, 2013, no. 9, pp. 5-11.

21. Kachalov A., Kurylev Ya., Lassas M. Inverse Boundary Spectral Problems. Florida, CRC Press, 2001. DOI: 10.1201/9781420036220

22. Litvinenko O.N., Soshnikov V.I. Teoriya neodnorodnyh linij $i$ ih primenenie $v$ radiotekhnike [Theory of Inhomogeneous Lines and Their Application in Radio Engineering]. Moscow, Sovetskoe radio, 1964. (in Russian)

23. Meshchanov V.P., Feldshtein A.L. Avtomatizirovannoe proektirovanie napravlennyh otvetvitelej SVCH [Automated Design of Directed Branches of SVCH]. Moscow, Svyaz, 1980. (in Russian)

24. Miropolskii Yu.Z. Dinamika vnutrennih gravitacionnyh voln v okeane [Dynamics of Internal Gravity Waves in the Ocean]. Leningrad, Gidrometeoizdat, 1981. (in Russian)

25. Maximov V.I. Zadacha dinamicheskogo vosstanovleniya vhodov beskonechnomernyh sistem [The Problem of Dynamic Input Restoration of Infinite-Dimensional Systems]. Ekaterinburg, URO RAN, 2000. (in Russian)

26. Polskii N.I. [Some Generalizations of the Galerkin Method]. Doklady Akademii Nauk SSSR, 1952, vol. 46, no. 1, pp. 469-472. (in Russian)

27. Polskii N.I. [On the Convergence of Some Approximate Methods of Analysis]. Ukrainian Mathematical Journal, 1955, vol. 7, no. 1, pp. 56-70. (in Russian)

28. Polskii N.I. [About One General Scheme of Using Approximate Methods]. Doklady Akademii Nauk SSSR, 1956, vol. 111, no. 6, pp. 1181-1183. (in Russian)

29. Potetyunko E.N. [Determining the Density of the Ocean by a Single Frequency and the Corresponding Wave Number in the Problem of Free Oscillations of the Ocean]. Mezhdunarodnyj zhurnal prikladnyh i fundamental'nyh issledovanii, 2011, no. 10, pp. 55-58.

30. Potetyunko E.N. [Inverse Spectral Problems]. Uspekhi sovremennogo estestvoznaniya, 2011, no. 2, pp. 99-104. (in Russian) 
31. Potetunko E.N., Scherbak Ye.N. The Inverse Spectral Problem in the Detection of the Defect End Heteroge. Mexico City, Eneititles os the Civil Engeneering, 2005. DOI: $10.1061 / 40794(179) 106$

32. Potetyunko E.N., Cherkesov L.V., Shubin D.S., Scherbak E.N. Svobodnye kolebaniya $i$ obratnye spektral'nye zadachi. Volnovye dvizheniya neodnorodnoj zhidkosti [Free Vibrations and Inverse Spectral Problems. Wave Motion Heterogeneous Fluid]. Moscow, Vuzovskaya kniga, 2001. (in Russian)

33. Polyakov A.V. Determination of Atmospheric Gas Composition and Aerosol Characteristics by the Eclipsing Method: D.Sc. Thesis. Saint-Petersburg, 2006.

34. Sadovnchii V.A., Dubrovskii V.V. [A Note on One New Method for Computing Eigenvalues and Eigenfunctions of Discrete Operators]. Trudy Seminara imeni I.G. Petrovskogo, 1994, no. 17, pp. 244-248. (in Russian)

35. Sadovnchii V.A., Dubrovskii V.V., Smirnova L.V. [On the Uniqueness of the Solution of Inverse Problems of Spectral Analysis]. Doklady Akademii Nauk SSSR, 2000, vol. 370, no. 3, pp. 19-321. (in Russian)

36. Sadovnchii V.A., Dubrovskii V.V., Puzankova E.A. The Inverse Problem of Spectral Analysis for a Power of the Laplace Operator in the Rectangle. Differential Equations, 2000, vol. 6, no. 12 , pp. 1859-1862.

37. Sharp T.E. Potential-Energy Curves for Molecular Hydrogen and Its Ions. Atomic Data and Nuclear Data Tables, 1971, vol. 2, pp. 119-169. DOI: 10.1016/S0092-640X(70)80007-9

38. Sedov A.I. On the Approximate Solution of the Inverse Problem of Spectral Analysis for the Degree of the Laplace Operator on a Rectangle. Bulletin of the South Ural State University. Series: Mathematical Modelling, Programming and Computer Software, 2010, no. 16 (192), issue 5, pp. 73-78. (in Russian)

39. Sedov A.I., Dubrovskii V.V. [The Inverse Problem of Spectral Analysis for a Single Partial Differential Operator with a Non-Nuclear Resolvent]. Elektromagnitnye volny $i$ ehlektronnye sistemy, 2005, vol. 10, no. 1, pp. 4-9.

40. Vo CHong Thak. Numerical Investigation of Models of Wave and Quantum Physics in the Formulation of Inverse Parametric Spectral Problem: PhD. Thesis. Moscow, Moscow State Technological University "STANKIN", 2013. (in Russian)

41. Valeev N.F. [On One Model for Controlling the Own Oscillations of Dynamic Systems]. Vestnik Ufimskogo gosudarstvennogo aviacionnogo tekhnicheskogo universiteta, 2008, no. 2, pp. 45-46. (in Russian)

42. Valeev N.F., Yumagulov M.G. [Inverse Spectral Problems of the Theory of Identification of Linear Dynamic Systems]. Avtomatika i Telemekhanika, 2009, no. 11, pp. 1776-1782.

43. Yurko V.A. Ob odnoy zadache teorii uprugosti [Introduction to the Theory of Inverse Spectral Problems]. Moscow, Fizmatlit, 2007. (in Russian)

44. Yurko V.A. A Problem in Elasticity Theory. Journal of Applied Mathematics and Mechanics, 1990, vol. 54, no. 6, pp. 820-824. DOI: 10.1016/0021-8928(90)90017-5

45. Zahariev B.N., Kostov N.A., Plekhanov E.B. Exactly Solvable One- and Multi-Channel Models (Lessons on Quantum Intuition). Physics of Elementary Particles and Atomic Nuclei, 1990, vol. 21, issue 4, pp. 914-962. (in Russian)

46. Znamenskaya L.N. Upravlenie uprugimi kolebaniyami [Control of Elastic Vibrations]. Moscow, Fizmatlit, 2004. (in Russian) 
47. Zakirova G.A., Sedov A.I. [The Inverse Problem of Spectral Analysis for the Perturbed Degree of the Laplace Operator in the Case of the Neumann Problem on a Parallelepiped]. Vestnik ChelGU. Matematika. Mekhanika. Informatika, 2008, vol. 10, no. 6, pp. 63-68. (in Russian)

48. Zakirova G.A. Approximate Solution of the Inverse Spectral Problem for the Laplace Operator. Bulletin of the South Ural State University. Series: Mathematical Modelling, Programming and Computer Software, 2008, vol. 2, no. 27 (127), pp. 19-27. (in Russian)

49. Zakirova G.A., Manakova N., Sviridyuk G. The Asymptotics of Eigenvalues of a Differential Operator in the Stochastic Models with "White Noise". Applied Mathematical Sciences, 2014, no. 8, pp. 8747-8754. DOI: 10.12988/ams.2014.49756

Received November 23, 2018

УДК 519.642.8

DOI: $10.14529 / \mathrm{mmp190201}$

\section{ОБРАТНЫЕ СПЕКТРАЛЬНЫЕ ЗАДАЧИ И МАТЕМАТИЧЕСКИЕ МОДЕЛИ МЕХАНИКИ СПЛОШНЫХ СРЕД}

Г.A. Закирова, Южно-Уральский государственный университет, г. Челябинск, Российская Федерация

Статья носит обзорный характер и содержит результаты в области спектральных задач для математических моделей с дискретным полуограниченным оператором. В основу теории положены линейные формулы вычисления собственных чисел дискретного оператора и редукция рассматриваемых спектральных задач к интегральному уравнению Фредгольма первого рода. Разработанный на основе метода Галеркина вычислительно эффективный численный метод решения обратных спектральных задач для дискретных полуограниченных операторов позволяет с высокой точностью восстанавливать коэффициентные функции краевых задач. Полученные результаты применимы при исследовании задач для дифференциальных операторов любого порядка. Приведены результаты численного решения обратной спектральной задачи для возмущенного дифференциального оператора четвертого порядка. Проведено исследование некоторых математических моделей механики сплошной среды на основе спектральных задач для дискретного полуограниченного оператора.

Ключевые слова: обратная спектральная задача; дискретный оператор; оператор четвертого порядка, самосопряженный оператор; собственные числа; собственные функции; некорректно поставленные задачи.

\section{Литература}

1. Ахтямов, А.М. Определение длины, плотности и модуля упругости коррозионного участка стержня по собственным частотам продольных колебаний / А.М. Ахтямов, Д.Р. Галеева // Вестник Башкирского университета. - 2015. - Т. 20, № 2. - С. 398-402.

2. Anderssen, R.S. The Effect of Discontinuities in Destiny and Shear Velocity on the Asymptotic Overtone Structure of Tortional Ejgenfrecuencies of the Earth / R.S. Anderssen // Astronomical Sciences. - 1997. - V. 50. - P. 303-309.

3. Anosova, E. Parameters of Physically Non-Homogenous Media Reconstructed from the Eigenfrequencies of Their Free Oscillations / Ye.A. Anosova, E.N. Potetunko, Ye.N. Scherbak // Journal of Engineering Mathematics. - 2006. - V. 55. - P. 339-356. 
4. Anosova, E. Assesment of the Efliqciency of the Structure Foundation by the Resonanse Frequencies of its Anti Planar Vibrations / E. Anosova, I. Herskowitz, E.N. Potetynko, L.S. Srubshchik // Strures Congress and the Forensic Engineering Symposium. - New York, 2005 .

5. Вибрации в технике: колебания линейных систем. - М.: Машиностроение, 1978.

6. Быков, А.А. Потенциальные модели кваркония / А.А. Быков, И.М. Дремин, А.В. Леонидов // Успехи физических наук. - 1984. - Т. 143, № 1. - С. 3-32.

7. Cherkesov, L.V. Reconstruction of Ocean Density Distribution From Its Wave Spectrum / L.V. Cherkesov, E.N. Potetunko, D.S. Shubin // International Journal of Fluid Mechanics Research. - 2003. - V. 30, № 1. - P. 11-23.

8. Дубровский, В.В. К обратной задаче для оператора Лапласа с непрерывным потенциалом / В.В. Дубровский, А.Н. Нагорный // Дифференциальные уравнения. - 1990. Т. 26, № 9. - С. 1563-1567.

9. Дубровский, В.В. Обратная задача для степени оператора Лапласа с потенциалом из $L^{2}$ / В.В. Дубровский, А.Н. Нагорный // Дифференциальные уравнения. - 1992. - Т. 28, № 9. - С. 1552-1561.

10. Дубровский, В.В. К устойчивости обратных задач спектрального анализа для уравнений математической физики/ В.В. Дубровский // Успехи математических наук. - 1994. Т. 49, № 3. - С. 171-172.

11. Дубровский, В.В. Восстановление потенциала по собственным значениям разных задач / В.В. Дубровский // Успехи математических наук. - 1996. - Т. 51, № 4. - С. 155-156.

12. Дубровский, В.В. Теорема существования в обратной задачи спектрального анализа / В.В. Дубровский // Дифференциальные уравнения. - 1997. - Т. 33, № 12. C. $1702-1703$.

13. Дубровский, В.В. Обратные задачи спектрального анализа для некоторых дифференциальных операторов в частных производных: дис. ... канд. физ.-мат. наук / В.В. Дубровский. - Магнитогорск, 2006.

14. Егоров, А.И. Основы теории управления / А.И. Егоров. - М.: Физматлит, 2004.

15. Грэхем, М., Глэдвелл Л. Обратные задачи теории колебаний / М. Грэхем, Л. Глэдвелл. М.: Регулярная и хаотическая динамика, 2008.

16. Favini, A. Linear Sobolev Type Equations with Relatively p-Sectorial Operators in Space of "Noises" / A. Favini, G.A. Sviridyuk, N.A. Manakova // Abstract and Applied Analysis. 2015. - V. 2015. - Article ID: 697410. - 8 p.

17. Кадченко, С.И. Численные методы регуляризованных следов спектрального анализа / С.И. Кадченко, С.Н. Какушкин. - Челябинск: Издат. центр ЮУрГУ, 2015.

18. Кадченко, С.И. Численный метод решения обратных спектральных задач, порожденных возмущенными самосопряженными операторами / С.И. Кадченко // Вестник СамГУ. Естественнонаучная серия. - 2013. - № 9. - С. 5-11.

19. Кадченко, С.И. А Numerical Method for Inverse Spectral Problems / S.I. Kadchenko, G.A. Zakirova // Вестник ЮУрГУ. Серия: Математическое моделирование и программирование. - 2015. - Т. 8, № 3. - С. 116-126.

20. Kadchenko, S.I. The Numerical Method of Solving of Inverse Spectral Problems Generated by Perturbed Self-Adjoint Operator / S.I. Kadchenko, G.A. Zakirova, A.I. Kadchenko // 2nd International Conference on Industrial Engineering, Applications and Manufacturing, ICIEAM 2016. - 2016. - Article ID:7911720. - 8 p. 
21. Литвиненко, О.Н. Теория неоднородных линий и их применение в радиотехнике / О.Н. Литвиненко, В.И. Сошников. - М.: Советское радио, 1964.

22. Kachalov, A. Inverse Boundary Spectral Problems / A. Kachalov, Y. Kurylev, M. Lassas. Florida: CPR Press, 2001.

23. Мещанов, В.П. Автоматизированное проектирование направленных ответвителей СВЧ / В.П. Мещанов, А.Л. Фельдштейн. - М.: Связь, 1980.

24. Миропольский, Ю.З. Динамика внутренних гравитационных волн в океане / Ю.З. Миропольский. - Л.: Гидрометеоиздат, 1981.

25. Максимов, В.И. Задача динамического восстановления входов бесконечномерных систем / В.И. Максимов. - Екатеринбург: УРО РАН, 2000.

26. Польский, Н.И. Некоторые обобщения метода Б.Г. Галеркина / Н.И. Польский // Доклады Академии наук СССР. - 1952. - Т. 46, № 1. - С. 469-472.

27. Польский, Н.И. О сходимости некоторых приближенных методов анализа / Н.И. Польский // Украинский математический журнал. - 1955. - Т. 7, № 1. - С. 56-70.

28. Польский, Н.И. Об одной общей схеме применения приближенных методов / Н.И. Польский // Доклады Академии наук СССР. - 1956. - Т. 111, № 6. - С. 1181-1183.

29. Потетюнко, Е.М. Определение плотности океана по одной частоте и соответствующему ей волновому числу, в задаче о свободных колебаниях океана / Е.М. Потетюнко // Международный журнал прикладных и фундаментальных исследований. - 2011. - № 10. C. $55-58$.

30. Потетюнко, Э.Н. Обратные спектральные задачи / Э.Н. Потетюнко // Успехи современного естествознания. - 2011. - № 2. - С. 99-104.

31. Potetunko, E.N. The Inverse Spectral Problem in the Detection of the Defect End Heteroge / E.N. Potetunko, Ye.N. Scherbak // Enetitles os the Civil Engeneering, Mexico. - 2005. P. 1-10.

32. Потетюнко, Э.Н. Свободные колебания и обратные спектральные задачи. Волновые движения неоднородной жидкости / Э.Н. Потетюнко, Л.В. Черкесов, Д.С. Шубин, Е.Н. Щербак. - М.: Вузовская книга, 2001.

33. Поляков, А.В. Определение газового состава атмосферы и характеристик аэрозоля затменным методом: дис. ... канд. физ.-мат. наук / А.В. Поляков. - Санкт-Петербург, 2006.

34. Садовничий, В.А. Замечание об одном новом методе вычислений собственных значений и собственных функций дискретных операторов / В.А. Садовничий, В.В. Дубровский // Труды семинара им. И.Г. Петровского. - 1994. - Т. 17. - С. 244-248.

35. Садовничий, В.А. О единственности решения обратных задач спектрального анализа / В.А. Садовничий, В.В. Дубровский, Л.В. Смирнова // Доклады Академии наук. 2000. - Т. 370, № 3. - С. 319-321.

36. Садовничий, В.А. Обратная задача спектрального анализа для степени оператора Лапласа на прямоугольнике / В.А. Садовничий, В.В. Дубровский, Е.А. Пузанкова // Дифференциальные уравнения. - 2000. - Т. 36, № 12. - С. 1693-1698.

37. Sharp, T.E. Potential-Energy Curves for Molecular Hydrogen and Its Ions / T.E. Sharp // Atomic Data and Nuclear Data Tables. - 1971. - V. 2. - P. 119-169.

38. Седов, А.И. О приближенном решении обратной задачи спектрального анализа для степени оператора Лапласа на прямоугольнике / А.И. Седов // Вестник ЮУрГУ. Серия: Математическое моделирование и программирование. - 2010. - Т. 16, № 5. - С. 73-78. 
39. Седов, А.И. Обратная задача спектрального анализа для одного дифференциального оператора в частных производных с неядерной резольвентой / А.И. Седов, В.В. Дубровский // Электромагнитные волны и электронные системы. - 2005. - Т. 10, № 1. C. 4-9.

40. Во Чонг Тхак. Численное исследование моделей волновой и квантовой физики в постановке обратной параметрической спектральной задачи: - М., 2013

41. Валеев, Н.Ф. Об одной модели управления собственными колебаниями динамических систем / Н.Ф. Валеев // Вестник Уфимского государственного авиационного технического университета. - 2008. - №. 2. - С. 142-149.

42. Валеев, Н.Ф. Обратные спектральные задачи в теории идентификации линейных динамических систем / Н.Ф. Валеев, М.Г. Юмагулов // Автоматика и телемеханика. 2009. - T. 11. - C. 13-20.

43. Юрко, В.А. Введение в теорию обратных спектральных задач. / В.А. Юрко. - М.: ФИЗМАТЛИТ, 2007.

44. Юрко, В.А. Об одной задаче теории упругости / В.А. Юрко // Прикладная математика и механика. - 1990. - Т. 54, № 6. - С. 998-1002.

45. Захарьев, Б.Н. Точно решаемые одно- и многоканальные модели (уроки квантовой интуиции I) / Б.Н. Захарьев, Н.А. Костов, Е.Б. Плеханов // Физика элементарных частиц и атомного ядра. - 1990. - Т. 21, № 4. - С. 914-962.

46. Знаменская, Л.Н. Управление упругими колебаниями / Л.Н. Знаменскаяю - М.: Физматлит, 2004.

47. Закирова, Г.А. Обратная задача спектрального анализа для возмущенной степени оператора Лапласа в случае задачи Неймана на параллелепипеде / Г.А. Закирова, А.И. Седов // Вестник ЧелГУ. Математика. Механика. Информатика. - 2008. - № 6. - С. 63-68.

48. Закирова, Г.А. Приближенное решение обратной спектральной задачи для оператора Лапласа / Г.А. Закирова // Вестник ЮУрГУ. Серия: Математическое моделирование и программирование. - 2008. - № 27 (127), вып. 2. - С. 19-27.

49. Zakirova, G.A. The Asymptotics of Eigenvalues of a Differential Operator in the Stochastic Models with «White Noise»/ G. Zakirova, N. Manakova, G. Sviridyuk // Applied Mathematical Sciences. - 2014. - № 8. - P. 8747-8754.

Галия Амрулловна Закирова, кандидат физико-математических наук, доцент, кафедра «Уравнения математической физики», Южно-Уральский государственный университет (г. Челябинск, Российская Федерация), zakirovaga@susu.ru.

Поступила в редакиию 23 ноября 2018 г. 